\title{
OPEM
}

www.opem.org

Oriental Pharmacy and Experimental Medicine 2009 9(2), 186-191

DOI 10.3742/OPEM.2009.9.2.186

\section{Anti-cancer effect of Eriocaulon sieboldianum through the activation of caspase-3 in human leukemia cell line, HL-60 cells}

\author{
Su-Jin Kim ${ }^{1, a}$, Gi-Tak Lee ${ }^{2, a}$, Bo-Ra Lee ${ }^{2}$, Kwon-Su Jeon ${ }^{1}$, Hong-Kun Rim ${ }^{1}$, Jun-Ho Bang ${ }^{1}$, Yang- \\ Gwi Kim ${ }^{1}$, No-Yil Myung, ${ }^{1}$ Phil-Dong Moon ${ }^{1}$, Na-Hyung Kim ${ }^{1}$, In-Young Choi ${ }^{1}$, Young-jin Choi ${ }^{3}$, \\ In-Cheol Kang ${ }^{3}$, Jae-Young Um ${ }^{1}$, Seung-Heon Hong ${ }^{2}$, Hyung-Min Kim ${ }^{1}$ and Hyun-Ja Jeong ${ }^{3, *}$ \\ ${ }^{1}$ College of Oriental Medicine, Institute of Oriental Medicine, Kyung Hee University, 1 Hoegi-Dong, Dongdaemun-Gu, \\ Seoul, 130-701, Republic of Korea; ${ }^{2}$ College of Oriental Medicine, Wonkwang University, Iksan, Chonbuk, 570- \\ 749, Republic of Korea; ${ }^{3}$ Biochip Research Center, Hoseo University, 165 Sechul-ri, Baebang-myun, Asan, \\ Chungnam, 336-795, Republic of Korea
}

Received for publication May 04, 2009; accepted May 18, 2009

\begin{abstract}
SUMMARY
Eriocaulon sieboldianum (ES) is used in traditional oriental medicine for various medicinal purposes including headache, toothache, and inflammation. However, the anti-cancer effect of the ES is still not fully understood. In the present study, the human leukemia cell line HL-60 was used to characterize the apoptotic effects of ES. ES induced cytotoxicity of HL-60 cells in a doseand time-dependent manner. ES induced the generation of reactive oxygen species, and the release of cytochrome $c$ in a dose-dependent manner. In addition, we showed that ES-induced apoptosis was accompanied by activation of caspase-3. Taken together, our results demonstrate that ES possesses anti-cancer activity in HL-60 cells.
\end{abstract}

Key words: Eriocaulon sieboldianum; Reactive oxygen species; Cytochrome c; Caspase-3

\section{INTRODUCTION}

Apoptosis plays not only an essential role in development and tissue homeostasis but is also involved in a wide range of pathological conditions (De Martinis et al., 2007; Gatzka and Walsh, 2007; Van Heemst et al., 2007). In mammalian cells, there are two major caspase activation pathways: the extrinsic and the intrinsic pathways. In the extrinsic pathway binding of death receptors, causes activation of caspase-8, the initiator caspase, which then

*Correspondence: Hyun-Ja Jeong, Biochip Research Center, Hoseo University, 336-795, Republic of Korea. Tel: +82415409681; Fax: +82415429681; E-mail:hjjeong @hoseo.edu

${ }^{a}$ The authors were equally contributed to this work. activates other caspase- 3 and others, the effector caspases. In the intrinsic pathway, various forms of cellular stress result in mitochondrial alterations leading to mitochondrial membrane depolarization (MMP) and the release of cytochrome c (cyt c). In the cytosol, cyt $\mathrm{c}$ binds to and activates Apaf-1 which itself activates pro-caspase-9. Active caspase-9 has been shown to directly cleave and activate effecter protease, caspase-3.

In many systems, apoptosis is associated with the loss of MMP, which may be regarded as a limiting factor in the apoptotic pathway. The mitochondrial membrane presents an electrochemical gradient (DYm), and the collapse of DYm leads to mitochondrial outer membrane permeabilization that favors cyt c release into the cytosol causing an 
activation of cell death (Garrido et al., 2006). Mitochondria dysfunction may also lead to ROS production that can damage proteins and DNA (Valko et al., 2004).

Eriocaulon sieboldianum (ES) is used in traditional oriental medicine for various medicinal purposes including headache, toothache, and inflammation. However, the anti-cancer effect of the ES is still not fully understood. In order to gain further insights into the mechanism of ES-induced apoptosis in HL-60 cells, the objectives of this study were as follows: (I) To examine the effect of ES on cell death; (II) to investigate the effect of ES on ROS generation, cyt c release, and caspase- 3 activation.

\section{MATERIALS AND METHODS}

\section{Reagents}

Fetal bovine serum (FBS) was purchased from Gibco BRL (Grand Island, NY, USA). Dimethyl sulfoxide (DMSO), 3-(4, 5-dimethylthiazol-2-yl)-2, 5-diphenyltetrazolium bromide (MTT), isopropanol, sodium dodecyl sulfate (SDS), bicinchoninic acid (BCA) and other reagents were purchased from Sigma Chemical (St. Louis, MO, USA). Anti-human caspase-3 antibody was obtained from Santa Cruz Biotechnology, Inc. (Santa Cruz, CA, USA). The caspase assay kit was supplied by $R$ \& D system Inc. (Minneapolis, MN, USA).

\section{Preparation of ES}

ES was obtained from the College of Pharmacy, Wonkwang University (Iksan, South Korea). Extract of ES was prepared by decocting the dried description of herbs with boiling distilled water. The extraction decocted for approximately $3 \mathrm{~h}$ has been filtered, lyophilized, and kept a $4{ }^{\circ} \mathrm{C}$. The yield of extraction was about $2 \%$. Dilutions were made in saline then filtered through $0.22 \mathrm{~mm}$ syringe filter.

\section{Culture of HL-60 cells}

HL-60 cells were obtained from Korean Cell Line Bank (Seoul, Korea). HL-60 cells were maintained in RPMI 1640 medium containing 10\% heatinactivated FBS supplemented with $100 \mathrm{unit} / \mathrm{ml}$ penicillin and $100 \mathrm{unit} / \mathrm{ml}$ streptomycin at $37^{\circ} \mathrm{C}$ under $5 \% \mathrm{CO}_{2}$ in air.

\section{MTT assay}

To test the viability of cells, MTT colorimetric assay was performed as described previously (Kim et al., 2001). Briefly, cells $\left(1 \times 10^{5}\right.$ cells $\left./ \mathrm{ml}\right)$ were incubated for $24 \mathrm{~h}$ after incubation in the absence or presence of ES. After addition of MTT solution, the cells were incubated at $37^{\circ} \mathrm{C}$ for $4 \mathrm{~h}$. The crystallized MTT was dissolved in DMSO and measured the absorbance at $540 \mathrm{~nm}$.

\section{Spectrofluorimetric measurement of intracellular ROS generation}

The intracellular ROS levels were measured using a fluorescent dye, 2, 7-dichlorofluorescein diacetate (DCFH-DA). In the presence of an oxidant, DCFH is converted to a highly fluorescent molecule, 2, 7dichlorofluorescein (DCF). The cells were cultured in the presence or absence of ES, and incubated for 30 min with DCFH-DA $(5 \mu \mathrm{M})$. The fluorescence intensity was measured using a spectrofluorometer (SHIMADZU Corporation, Japan) at an excitation and emission wavelength of 485 and $538 \mathrm{~nm}$, respectively.

\section{Western blot analysis}

For analysis of the levels of cyt $\mathrm{c}$ and pro-caspase-3, cells were rinsed twice with ice-cold PBS and were then lysed in ice-cold lysis buffer (1\% Triton, $1 \%$ Nonidet P-40, $0.1 \%$ SDS, $1 \%$ deoxycholate). Cell lysates were centrifuged at $15,000 \times \mathrm{g}$ for $5 \mathrm{~min}$ at $4^{\circ} \mathrm{C}$; the supernatant was then mixed with an equal volume of $2 \times$ SDS sample buffer, boiled for $5 \mathrm{~min}$, and then separated through $10 \%$ SDS-PAGE gels. After electrophoresis, the protein was transferred to nylon membranes by electrophoretic transfer. The membranes were blocked in 5\% skim milk for $2 \mathrm{~h}$, rinsed, and incubated overnight at $4{ }^{\circ} \mathrm{C}$ with primary antibodies in phosphate buffered saline 
(PBS) $/ 0.5 \%$ Tween 20. Excess primary antibody was then removed by washing the membranes four times in PBS/0.5\% Tween 20, and the membranes were incubated for $1 \mathrm{~h}$ with HRP-conjugated secondary antibodies (against mouse, or rabbit). After three washes in PBS/0.5\% Tween 20, the protein bands were visualized by an enhanced chemiluminesence assay (Amersham Pharmacia Biotech, NJ, USA) following the manufacturer's instructions.

\section{Measurement of caspase- 3 activity}

Caspase-3 activity was measured by a caspase assay kit ( $\mathrm{R} \& \mathrm{D}$ system). Cells were incubated with ES for $24 \mathrm{~h}$ at $37^{\circ} \mathrm{C}$. The cells were lyses on ice for $10 \mathrm{~min}$ using cell lysis buffer and centrifuged at $10,000 \times \mathrm{g}$ for $1 \mathrm{~min}$. Equal amount of total protein was quantified by BCA in each lysate. Catalytic activity of caspase-3 from cell lysate was measured by proteolytic cleavage of DEVD-pNA (caspase-3 colorimetric substrate) for $2 \mathrm{~h}$ at $37^{\circ} \mathrm{C}$. The plates were read at $405 \mathrm{~nm}$. Recombinant caspase-3 enzymes are available for use as a positive control.

\section{Statistical analysis}

The experiments shown are a summary of the data from at least-three experiments and are presented as the mean \pm S.E.M. Statistical evaluation of the results was performed by ANOVA with Turkey post hoc test. The results were considered significant at a value of $P<0.05$.

\section{RESULTS}

\section{Effect of ES on the cell viability in HL-60 cells}

First, the effect of ES on the viability of HL-60 cells was investigated. The cells were either incubated with ES at different concentrations $(0.01-1 \mathrm{mg} / \mathrm{ml})$ for $24 \mathrm{~h}$, or treated with ES at a constant concentration $(1 \mathrm{mg} / \mathrm{ml})$ for varying periods $(4-24 \mathrm{~h})$. The cell viability was measured using the MTT assay. The results showed that ES reduced the cell viability in a dose- and time- dependent manner (Fig. 1).
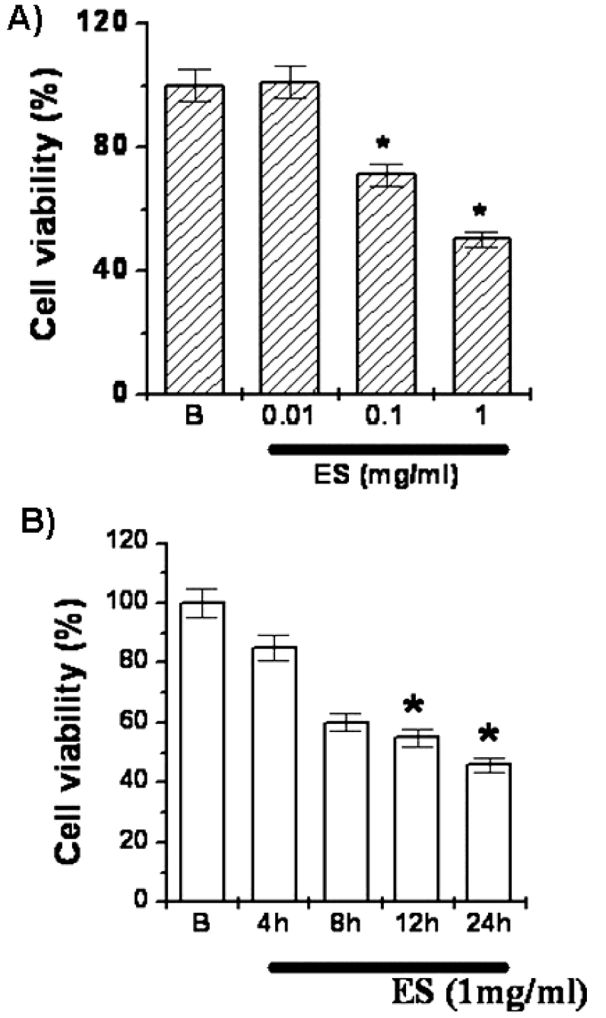

Fig. 1. The effect of ES on the cell viability. A) Cells (3 $\times 10^{5}$ ) were pretreated with various concentrations of ES for $24 \mathrm{~h}$, and then collected and assessed for viability. B) Cells $\left(3 \times 10^{5}\right)$ were treated with ES for various time courses and then collected and assessed for viability using MTT. Values are the mean \pm S.E.M. of duplicate determinations from three separate experiments. ${ }^{*} P<0.05$, significantly different from the ES untreated cells.

Effect of ES on the ROS generation in HL-60 cells To determine the effect of ES on the ROS generation, the cells were incubated with or without ES during different time periods and loaded with DCF-DA, which is converted into a fluorescent molecule after intracellular oxidation. DCFHDA, a nonfluorescent cell-membrane permeable probe, was used to penetrate the cells, react with cellular esterase and ROS, and then metabolize into fluorescent DCF. Incubation of HL-60 cells with ES caused a significant increase in fluorescence response. The maximum ROS increase was observed at $8 \mathrm{~h}$ after treatment of ES. However, the DCF 


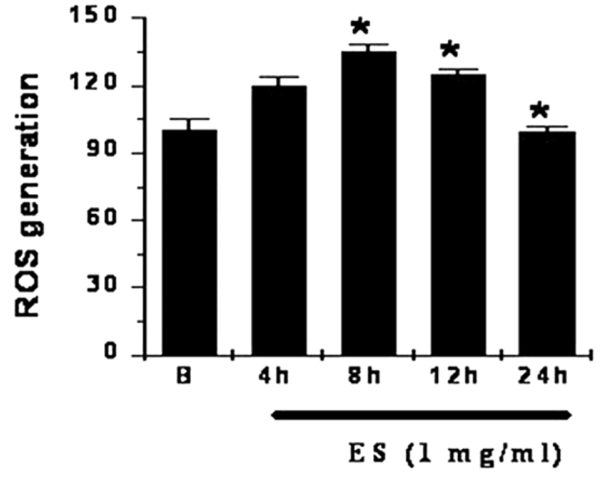

Fig. 2. The effect of ES on the ROS generation in HL60 cells. Cells $\left(3 \times 10^{5} /\right.$ well $)$ were treated with ES various time course. After treatment with ES, cells were loaded with fluorescent probe DCFH-DA and fluorescence was measured. Data are mean \pm S.E.M. of three independent experiments performed in duplicate. ${ }^{*} P<0.05$, significantly different from the ES untreated cells.

fluorescence declined subsequently because of significant cell death. The result showed that ES induce ROS generation in HL-60 cells (Fig. 2).

\section{Effect of ES on the cyt c release}

Cyt $\mathrm{c}$ is released following MMP, and plays a major role in cell death (Garrido et al., 2006). To determine the effect of ES on the cyt $\mathrm{c}$ release from mitochondrial into the cytosol, Western blot analysis was performed. As shown in Fig. 3, we observed that ES increase the cyt $c$ release into cytosolic.

\section{Effect of ES on the caspase-3 activation}

Pro-apoptotic stimuli induce MMP and promote release of cyt $\mathrm{c}$ in the cytosol leading to activation of pro-apoptotic factors as well as the maturation of caspase-3. In the present study, the extent to which ES influences the caspase-3 activity was investigated. To investigate whether ES regulate the caspase-3 activation, we performed the Western blot analysis. Cells were pretreated with ES (0.01 $1 \mathrm{mg} / \mathrm{ml}$ ) for $24 \mathrm{~h}$. As shown in Fig. 4A, we observed that ES decreased the pro-caspase-3 expression, an inactive form of caspase-3. Next, to

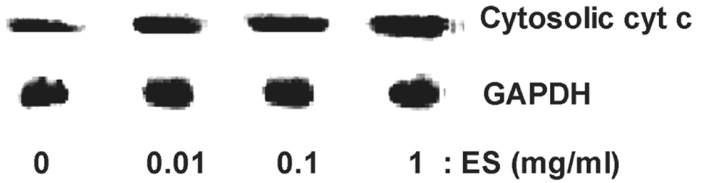

Fig. 3. The effect of ES on the cyt c release in HL-60 cells. Cells $\left(5 \times 10^{6}\right)$ were treated with ES for various concentrations for $24 \mathrm{~h}$. After isolation of cytosolic fraction, the protein extracts were assayed for cyt c by Western blot analysis. $\beta$-actin was used as the loading control.

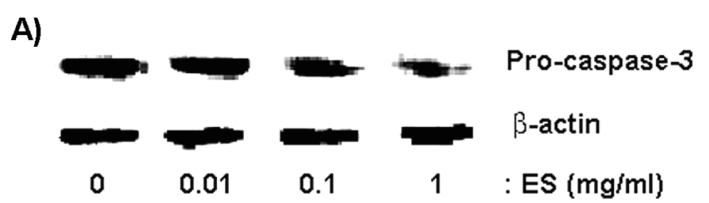

B)

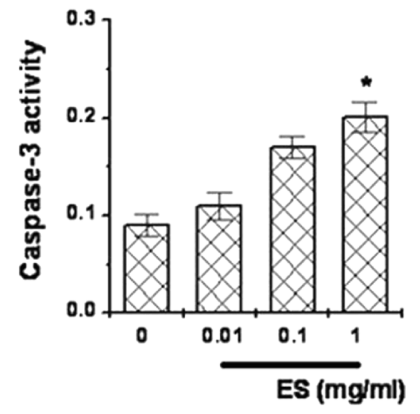

Fig. 4. The Effect of ES on the caspase-3 activation. A) Cells $\left(5 \times 10^{6} /\right.$ well $)$ were treated with various concentrations of ES $(0.01-1 \mathrm{mg} / \mathrm{ml})$ for $24 \mathrm{~h}$. The protein extracts were assayed by Western blot analysis for caspase-3. GAPDH was used for loading control. B) Cells $\left(3 \times 10^{6} /\right.$ well $)$ were treated with various concentrations of ES $(0.01-1 \mathrm{mg} / \mathrm{ml})$ for $24 \mathrm{~h}$. Caspase-3 activities were determined by a colorimetric kit using substrates. ${ }^{*} P<0.05$, significantly different from nottreated cells.

confirm if ES inhibit the caspase-3 activation, we used caspase-3 assay kit. As shown in Fig. 4B, ES induced the caspase-3 activation.

\section{DISCUSSION}

ES, in traditional herb, has been used for the treatment of various diseases. However, the effect and mechanism of ES on anti-cancer have not been examined. In present study, our findings show that 
ES induces cell death, ROS generation, and cyt $\mathrm{c}$ release into cytosol. In addition, ES increased the activation of caspase-3 in HL-60 cells.

Apoptosis plays not only an essential role in development and tissue homeostasis but is also involved in a wide range of pathological conditions (De Martinis et al., 2007; Gatzka and Walsh, 2007; Van Heemst et al., 2007). Apoptosis results in numerous cellular changes, such as membrane blebbing, nuclear condensation, and cell shrinkage (Plenchette et al., 2004). In this study, we observed that ES induced the cell death in a time- and dosedependent manner. ROS may be the causative factor involved in many human degenerative diseases. Antioxidants have been found to have some degree of preventive and therapeutic effects on these disorders (Ames et al., 1993). ROS may induce cell death directly or act as intracellular messengers during cell death induced by various other kinds of stimuli (Pathak et al., 2006). In many systems, apoptosis is associated with the loss of MMP, which may be regarded as a limiting factor in the apoptotic pathway. The mitochondrial membrane presents an DYm, and the collapse of DYm leads to mitochondrial outer membrane permeabilization that favors cyt $\mathrm{c}$ release into the cytosol causing an activation of cell death (Garrido et al., 2006). Mitochondria dysfunction may also lead to ROS production that can damage proteins, and DNA (Valko et al., 2004). In this study, we showed that ES increase the ROS generation, and cyt $\mathrm{c}$ release. These results suggest that ES induces apoptosis through apoptotic signal pathway of mitochondria.

The caspase family of aspartate-specific cysteine proteases is emerging as the central executioner of apoptosis (Putt et al., 2006). Caspase-3 is activated in a variety of cell types during apoptosis. Caspase3 is the final executioner enzyme associated with cell death during stimuli-induced apoptosis (Ohta et al., 1997). Once activated, caspase-3 is free to initiate the various processes involved in apoptosis (Nuez et al., 1998). Activated caspase-3 is found only in cells undergoing apoptosis and consists of p18 and p12 subunits that are derived from a 32 $\mathrm{kDa}$ proenzyme by cleavage at multiple aspartic acid sites (Schlegel et al., 1996). Protease caspase-3 can cleave and inactivate poly (ADP-ribose) polymerase, an enzyme that is used for DNA repair (Piedrafita et al., 1997). In this study, we observed the ES induced activation of caspase-3. These results demonstrated that ES show the anticancer effect via the suppression of caspase-3 activation.

In conclusion, we showed that ES induced ROS generation, cyt c release, and caspase-3 activation. Taken together, our results demonstrate that ES possesses anti-cancer activity in HL-60 cells.

\section{ACKNOWLEDGEMENTS}

This research was supported by the Academic Research fund of Hoseo University in 2008 (20080108).

\section{REFERENCES}

Ames BN, Shigenaga MK, Hagen TM. (1993) Oxidants, antioxidants, and the degenerative diseases of aging. Proc. Natl. Acad. Sci. U.S.A. 90, 7915-7922.

De Martinis M, Franceschi C, Monti D, Ginaldi L. (2007) Apoptosis remodeling in immunosenescence: implications for strategies to delay ageing. Curr. Med. Chem. 14, 1389-1397.

Garrido C, Galluzzi L, Brunet M, Puig PE, Didelot C, Kroemer G. (2006) Mechanisms of cytochrome c release from mitochondria. Cell Death Differ. 13, 1423-1433.

Gatzka M, Walsh CM. (2007) Apoptotic signal transduction and T cell tolerance. Autoimmunity 40, 442-452.

Kim MS, Lim WK, Cha JG, An NH, Yoo SJ, Park JH, Kim HM, Lee YM. (2001) The activation of PI 3-K and PKC zeta in PMA-induceddifferentiation of HL-60 cells. Cancer Lett. 171, 79-85.

Na HJ, Jeong HJ, Bae H, Kim YB, Park ST, Yun YG, Kim HM. (2002) Tongkyutang inhibits mast celldependent allergic reactions and inflammatory 
cytokines secretion. Clin. Chim. Acta 7, 35-41.

Nuez G, Benedict M, Hu Y, Inohara N. (1998) Caspases: the proteases of the apoptotic pathway. Oncogene 17, 3237-3245.

Ohta T, Kinoshita T, Naito M, Nozaki T, Masutani M, Tsuruo T, Miyajima A. (1997) Requirement of the caspase-3/CPP32 protease cascade for apoptotic death following cytokine deprivation in hematopoietic cells. J. Biol. Chem. 272, 23111-23116.

Pathak N, Khandelwal S. (2006) Influence of cadmium on murine thymocytes: Potentiation of apoptosis and oxidative stress. Toxicol. Lett. 165, 121-132.

Piedrafita FJ, Pfahl M. (1997) Retinoid-induced apoptosis and Sp1 cleavage occur independently of transcription and require caspase activation. Mol. Cell. Biol. 17, 6348-6358.

Plenchette S, Filomenko R, Logette E, Solier S, Buron N, Cathelin S, Solary E 2004. Analyzing markers of apoptosis in vitro. Methods Mol. Biol. 281, 313-331.

Putt KS, Chen GW, Peatson JM, Sandhorst JS, Hoagland MS, Kwon JT, Hwang SK, Jin H, Churchwell MI Cho MH, Doerge DR, Helferich WG, Hergenrother PJ. (2006) Small-molecule activation of procaspase-3 to caspase-3 as a personalized anticancer strategy. Nat. Chem. Biol. 2, 543-550.

Schlegel J, Peters I, Orrenius S, Miller DK, Thornberry NA, Yamin TT, Nicholson DW. (1996) CPP32/apopain is a key interleukin 1 beta converting enzyme-like protease involved in Fas-mediated apoptosis. J. Biol. Chem. 271, 1841-1844.

Valko M, Izakovic M, Mazur M, Rhodes CJ, Telser J. (2004) Role of oxygen radicals in DNA damage and cancer incidence. Mol. Cell. Biochem. 266, 37-56.

Van Heemst D, den Reijer PM, Westendorp RG. (2007) Ageing or cancer: A review On the role of caretakers and gatekeepers. Eur. J. Cancer 43, 2144-2152. 